\title{
Distribution and habitats of Melanoides tuberculata (Müller, 1774) and M. victoriae (Dohrn, 1865) (Mollusca: Prosobranchia: Thiaridae) in South Africa
}

\author{
KN de Kock ${ }^{1 *}$ and CT Wolmarans ${ }^{2}$ \\ ${ }^{1}$ Unit for Environmental Sciences and Management, Potchefstroom Campus of the North-West University, Private Bag X6001, \\ Potchefstroom 2520, South Africa \\ ${ }^{2}$ School of Environmental Sciences and Development, Zoology, Potchefstroom Campus of the North-West University, Private Bag \\ X6001, Potchefstroom 2520, South Africa
}

\begin{abstract}
An account is given of the geographical distribution and habitats of Melanoides tuberculata (Müller, 1774) and M. victoriae (Dohrn, 1865) as reflected by the samples on record in the database of the National Freshwater Snail Collection (NFSC) of South Africa. About 30 species of Melanoides occur in Africa of which only M. tuberculata is widespread. Melanoides tuberculata is also indigenous to India and the south-east Asian mainland to northern Australia and was widespread in the present-day Sahara during the late Pleistocene-Holocene, but $M$. victoriae seems to be restricted to Southern Africa. Details of the habitats on record for each species, as well as mean altitude and mean annual air temperature and rainfall for each locality, were processed to determine chi-square and effect-size values. An integrated decision-tree analysis indicated that temperature, altitude and type of substratum were the most important factors of those investigated that played a significant role in establishing the geographical distribution of these species in South Africa. In view of the fact that M. tuberculata can serve as intermediate host for a number of trematode species elsewhere in the world, it is recommended that the ability of the 2 local Melanoides species to act as intermediate hosts should be investigated. Due to the fact that the majority of sites from which these species were recovered were not since revisited, it is recommended that efforts should be made to update their geographical distribution and the results compared with the data in the database. The conservation status of these 2 species and the possible influence of global warming and climatic changes on their geographical distribution are briefly discussed.
\end{abstract}

Keywords: Melanoides tuberculata, Melanoides victoriae, geographical distribution, habitat preferences, biological control, Trematoda, freshwater Mollusca, South Africa

\section{Introduction}

The genus Melanoides is evidently restricted to the Old World tropics (Pilsbry and Bequaert, 1927) and about 30 species occur in Africa of which only M. tuberculata (Müller, 1774) is widespread (Brown, 1994). Melanoides tuberculata was described from the Coromandel coast of India in 1774 and its present-day distribution is the Indo-Pacific region, Southern Asia, Arabia, northern Australia, Near East and much of Africa (Appleton, 2002) and was also introduced into the Caribbean area (Brown, 1994). With regard to South Africa, only 2 species, namely $M$. tuberculata and M. victoriae (Dohrn, 1865) have been reported of which the former is the most widespread according to the records of the National Freshwater Snail Collection (NFSC). While M. tuberculata was also widespread in the present-day Sahara (Van Damme, 1984) M. victoriae seems to be restricted to Southern Africa (Brown, 1994; Appleton, 2002).

Melanoides tuberculata has proved to be a compatible intermediate host for several trematode species elsewhere in the world and shedding of cercariae of a number of trematode families has also been recorded for this snail species elsewhere in Africa (Frandsen and Christensen, 1984). It has become

\footnotetext{
* To whom all correspondence should be addressed.

兽 +2718 299-2380; fax: +2718 299-2370;

e-mail: kenne.dekock@nwu.ac.za

Received 4 November 2008; accepted in revised form 28 August 2009.
}

invasive after its introduction into new territories such as Martinique Island (Pointier, 2001) and Brazil (Rocha-Miranda and Martins-Silva, 2006) but also proved to be an efficient and sustainable bio-control agent of Biomphalaria glabrata (Say, 1818) the intermediate host snail of the intestinal schistosome parasite in these areas.

This paper focuses on the geographical distribution and habitat preferences of $M$. tuberculata and $M$. victoriae as reflected by the data in the database of the NFSC. In view of the fact that the records in the NFSC span a period of several decades the possible influence of global warming and climatic changes on the geographical distribution of these species in South Africa and their conservation status is briefly discussed.

\section{Methods}

Data from 1956 to the present (2009) on the geographical distribution and habitats of M. tuberculata and M. victoriae as recorded at the time of the survey were extracted from the NFSC database. Only those samples that could be located on a 1:250 000 topo-cadastral map series of South Africa were included in the analyses. The majority of these samples were collected during surveys conducted by government and local health authority staff, as well as staff of the former Snail Research Unit at the Potchefstroom University (now the NorthWest University). The number of loci ( $1 / 16$ degree squares) in which the collection sites were located, was distributed 
in intervals of mean annual air temperature and rainfall, as well as intervals of mean altitude to illustrate the frequency of occurrence of these species in water-bodies falling within specific intervals. Rainfall, temperature and altitude data were obtained in 2001 from the Computing Centre for Water Research (CCWR), University of KwaZulu-Natal (disbanded since). All mollusc species in the database were ranked in order of their association with low to high climatic temperatures according to a temperature index calculated from their frequencies of occurrence within selected temperature intervals. The method of calculation is dealt with in detail in our earlier publications (De Kock and Wolmarans, 2005a; b). To determine the significance in differences between frequency of occurrence in, on, or at the range of options for each factor investigated, chi-square values (Statistica, Release 7, Nonparametrics, 2X2 Tables, McNemar, Fischer exact) were calculated. An effect size was also calculated (Cohen, 1977) for each parameter investigated to evaluate the importance of its contribution towards establishing the geographical distribution of this species as reflected by the samples in the NFSC database. The method of calculation is explained with reference to the 14 different water-body types represented in the database. The first step is to determine the total number of times each water-body type, for instance rivers ( 7507 ), was reported for all the different mollusc species in the database and then to sum the total number of records of all the waterbodies reported for all the species in the database (28 956). To determine the $p$ value for each of the different water-body types, for instance for rivers as such, the frequency of occurrence of all species in rivers ( 7507 ) is divided by the total number of times (28 956) all the water-bodies were recorded in the database. The total number of times a specific mollusc species was reported from all 14 water-bodies together is then summed (this figure for M. tuberculata, for instance, was 228). The number of times a specific species was reported from a specific water-body type is then designated as ' $\mathrm{A}$ '. To determine a value designated as ' $B$ ' the number of times a specific species was reported from a specific water-body, for instance rivers (79), is multiplied by the $p$ value calculated for rivers (0.259). This is done for all the different water-body types from which this specific species was reported. Chi-square values $\left(x^{2}\right)$ for each type of water-body are then calculated as follows:

$$
\frac{(\mathrm{B}-\mathrm{A})^{2}}{\mathrm{~B}}
$$

$$
\mathrm{B}
$$

The chi-square values calculated for all the different waterbody types are then summed and the effect size $(w)$ for waterbodies as such is then calculated as follows: square root of $\Sigma x^{2}$ divided by $\Sigma$ A. Values for this index in the order of 0.1 and 0.3 indicate small and moderate effects respectively, while values of 0.5 and higher point to practically significant and large effects (Cohen, 1977). More details of the significance and interpretation of specific values calculated for this statistic in a given situation, are discussed in our earlier publications (De Kock and Wolmarans, 2005a; b).

A decision tree which is a multivariate analysis (Breiman et al., 1984) was also constructed from the data which enables the selection and ranking of those parameters that played the most important role in establishing the documented geographical distribution of these species, based on the data in the database. The frequencies of occurrence within the different options for a specific parameter which do not differ significantly from one another, are grouped together in the decision-tree analysis. If, for instance, the frequency of occurrence in rivers does not

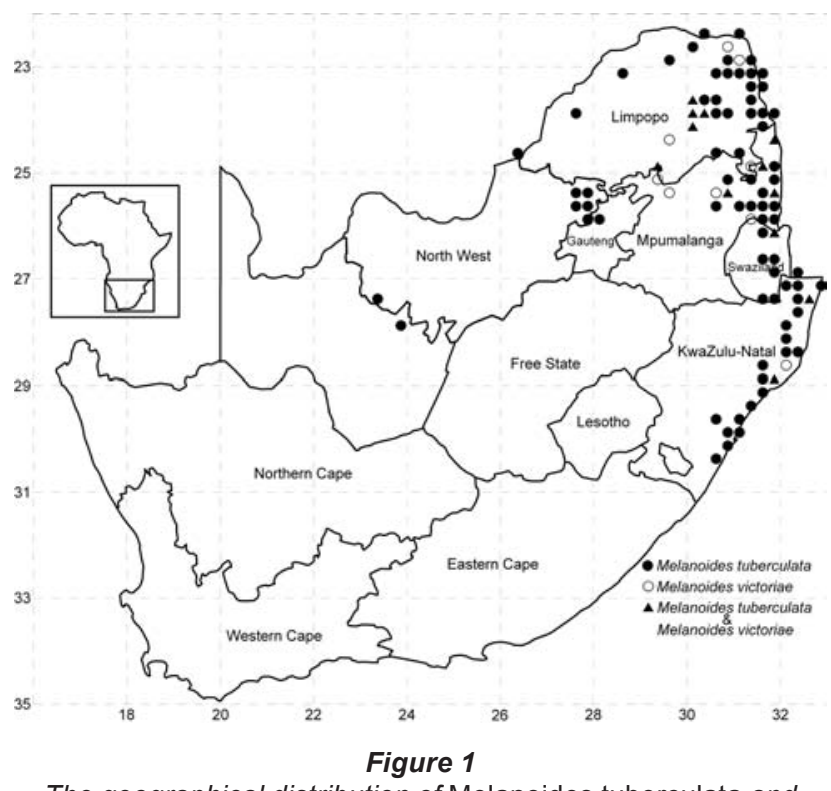

The geographical distribution of Melanoides tuberculata and M. victoriae in 1/16 square degree loci in South Africa as reflected by the records in the database of the National Freshwater Snail Collection

differ significantly from that in streams, these 2 options for water-bodies are grouped together in the decision tree analysis. In addition, the total number of times any other mollusc species in the database was recorded under a specific condition is also displayed in the results of the decision tree analysis. This analysis was done with the SAS Enterprise Miner for Windows NT Release 4.0, April 19, 2000 programme and Decision Tree Modelling Course Notes (Potts, 1999).

\section{Results}

The collection sites of the 305 samples of $M$. tuberculata fell within 85 and the 53 sites of $M$. victoriae within 21 different loci (Fig. 1). The former species was recovered from 12 of the 14 water-body types represented in the database while the latter species were found in only 6 (Table 1 ). Although the majority of samples of both species were recovered from rivers the highest percentage occurrence $(5.9 \%)$ in the total number of collections in a specific water-body for M. tuberculata $(0.9 \%)$ was realised in channels and that for M. victoriae in concrete dams (Table 1). An effect-size value of larger than 0.5 was calculated for both species for water-bodies as such (Table 1). The majority of samples of both species were recovered from waterbodies described as perennial, with clear, freshwater (Table 2). While the largest number of samples of M. tuberculata came from habitats with standing water, $M$. victoriae was more frequently collected in slow running water and a relatively large effect size was calculated for this parameter (Table 2).

The majority of samples of M. tuberculata was recovered from water-bodies of which the substratum was described as either muddy or sandy while equal numbers of samples of $M$. victoriae were collected on stony and sandy substrata (Table 3). A large effect size $(w=0.5)$ was calculated for substratum types for both species (Table 3 ).

With regard to the frequency of occurrence within the different temperature intervals, the highest percentage of samples of M. victoriae was recorded from the $16^{\circ} \mathrm{C}$ to $20^{\circ} \mathrm{C}$ interval, while habitats falling within the $21^{\circ} \mathrm{C}$ to $25^{\circ} \mathrm{C}$ interval yielded the highest number of samples of M. tuberculata (Table 4). There was, 


\begin{tabular}{|c|c|c|c|c|c|c|c|}
\hline \multicolumn{8}{|c|}{$\begin{array}{c}\text { Table } 1 \\
\begin{array}{c}\text { Water-bodies from which Melanoides tuberculata and } M \text {. victoriae were recorded } \\
\text { out of the } 14 \text { different types represented in the database of the National } \\
\text { Freshwater Snail Collection }\end{array} \\
\end{array}$} \\
\hline & & \multicolumn{3}{|c|}{ M. tuberculata } & \multicolumn{3}{|c|}{ M. victoriae } \\
\hline Water-bodies & $\mathrm{A}$ & $\mathrm{B}$ & $\mathrm{C}$ & $\mathrm{D}$ & $\mathrm{B}$ & $\mathrm{C}$ & $\mathrm{D}$ \\
\hline Channel & 169 & 10 & $3.3 \%$ & $5.9 \%$ & 0 & & \\
\hline Concrete dam & 221 & 3 & $1.0 \%$ & $1.4 \%$ & 2 & $3.8 \%$ & $0.9 \%$ \\
\hline Dam & 8400 & 62 & $20.3 \%$ & $0.7 \%$ & 4 & $7.5 \%$ & $0.05 \%$ \\
\hline Ditch & 636 & 4 & $1.3 \%$ & $0.6 \%$ & 1 & $1.9 \%$ & $0.2 \%$ \\
\hline Irrigation furrow & 113 & 2 & $0.7 \%$ & $1.8 \%$ & 0 & & \\
\hline Pan & 306 & 10 & $3.3 \%$ & $3.3 \%$ & 0 & & \\
\hline Pond & 1566 & 17 & $5.6 \%$ & $1.1 \%$ & 1 & $1.9 \%$ & $0.06 \%$ \\
\hline Quarry & 122 & 0 & & & 0 & & \\
\hline River & 7507 & 79 & $25.9 \%$ & $1.1 \%$ & 35 & $66.0 \%$ & $0.5 \%$ \\
\hline Spring & 301 & 1 & $0.3 \%$ & $0.3 \%$ & 0 & & \\
\hline Stream & 7211 & 28 & $9.2 \%$ & $0.4 \%$ & 2 & $3.8 \%$ & $0.03 \%$ \\
\hline Swamp & 2076 & 11 & $3.6 \%$ & $0.5 \%$ & 0 & & \\
\hline Vlei & 103 & 0 & & & 0 & & \\
\hline Waterhole & 225 & 1 & $0.3 \%$ & $0.4 \%$ & 0 & & \\
\hline \multicolumn{2}{|l|}{ Effect size } & \multicolumn{3}{|c|}{$w=0.8$ (large effect) } & \multicolumn{3}{|c|}{$w=1.1$ (large effect) } \\
\hline \multicolumn{8}{|c|}{$\begin{array}{l}\text { A Number of times any mollusc was collected in a specific water-body } \\
B \text { Number of times collected in a specific water-body } \\
C \% \text { of the total number of collections }(\mathrm{M} \text {. tuberculata } 305 \text {; M. victoriae 53) on record for each species } \\
D \% \text { occurrence of each species in the total number of collections in a specific water-body }\end{array}$} \\
\hline
\end{tabular}

\begin{tabular}{|c|c|c|c|c|c|c|c|c|c|c|}
\hline \multicolumn{11}{|c|}{$\begin{array}{c}\text { Table } 2 \\
\text { Water conditions in the habitats of Melanoides tuberculata and } M . \text { victoriae as described during surveys }\end{array}$} \\
\hline \multirow{2}{*}{\multicolumn{2}{|c|}{ Species }} & \multicolumn{2}{|c|}{ Type } & \multicolumn{3}{|c|}{ Velocity } & \multicolumn{2}{|c|}{ Turbidity } & \multicolumn{2}{|c|}{ Salinity } \\
\hline & & Perennial & Seasonal & Fast & Slow & Standing & Clear & Muddy & Fresh & Brackish \\
\hline \multirow{5}{*}{$\begin{array}{l}\text { Melanoides } \\
\text { tuberculata } \\
\quad * 305\end{array}$} & $\mathrm{~A}$ & 198 & 14 & 25 & 75 & 119 & 166 & 37 & 188 & 5 \\
\hline & $\mathrm{B}$ & $64.9 \%$ & $4.6 \%$ & $8.2 \%$ & $24.6 \%$ & $39.0 \%$ & $54.4 \%$ & $12.1 \%$ & $61.6 \%$ & $1.6 \%$ \\
\hline & $\mathrm{C}$ & 22432 & 5350 & 2229 & 9501 & 16147 & 20408 & 6438 & 24089 & 657 \\
\hline & $\mathrm{D}$ & $0.9 \%$ & $0.3 \%$ & $1.1 \%$ & $0.8 \%$ & $0.7 \%$ & $0.8 \%$ & $0.6 \%$ & $0.8 \%$ & $0.8 \%$ \\
\hline & $\mathrm{E}$ & \multicolumn{2}{|c|}{$\begin{array}{c}w=0.3 \\
\text { (moderate effect) }\end{array}$} & \multicolumn{3}{|c|}{$\begin{array}{c}w=0.1 \\
\text { (small effect) }\end{array}$} & \multicolumn{2}{|c|}{$\begin{array}{c}w=0.1 \\
\text { (small effect) }\end{array}$} & \multicolumn{2}{|c|}{$\begin{array}{c}w=0.00 \\
\text { (no effect) }\end{array}$} \\
\hline \multirow{5}{*}{$\begin{array}{l}\text { Melanoides } \\
\text { victoriae } \\
\quad * 53\end{array}$} & $\mathrm{~A}$ & 46 & 1 & 8 & 28 & 10 & 34 & 6 & 40 & 0 \\
\hline & $\mathrm{B}$ & $86.8 \%$ & $1.9 \%$ & $15.1 \%$ & $52.8 \%$ & $18.9 \%$ & $64.2 \%$ & $11.3 \%$ & $75.5 \%$ & $0.0 \%$ \\
\hline & $\mathrm{C}$ & 22432 & 5350 & 2229 & 9501 & 16147 & 20408 & 6438 & 24089 & 657 \\
\hline & $\mathrm{D}$ & $0.2 \%$ & $0.01 \%$ & $0.4 \%$ & $0.3 \%$ & $0.06 \%$ & $0.17 \%$ & $0.09 \%$ & $0.17 \%$ & $0.0 \%$ \\
\hline & $E$ & \multicolumn{2}{|c|}{$\begin{aligned} w= & 0.4 \text { (moderate to } \\
& \text { large effect) }\end{aligned}$} & \multicolumn{3}{|c|}{$w=0.7$ (large effect) } & \multicolumn{2}{|c|}{$\begin{array}{l}w=0.2 \text { (small to } \\
\text { moderate effect) }\end{array}$} & \multicolumn{2}{|c|}{$\begin{array}{c}w=0.03 \\
\text { (small effect) }\end{array}$} \\
\hline \multicolumn{11}{|c|}{$\begin{array}{l}\text { A Number of times collected in a specific water condition } \\
B \% \text { of the total number of collections on record for each species } \\
C \text { Number of times any mollusc was collected in a specific water condition } \\
D \% \text { occurrence of each species in the total number of collections in a specific water condition } \\
E \text { Effect size values calculated for each factor } \\
* \text { Number of collections on record for each species }\end{array}$} \\
\hline
\end{tabular}

however, no significant difference $(\mathrm{p}<0.05)$ between the frequency of occurrence of $M$. victoriae in habitats falling within the $16^{\circ} \mathrm{C}$ to $20^{\circ} \mathrm{C}$ and $21^{\circ} \mathrm{C}$ to $25^{\circ} \mathrm{C}$ intervals. The temperature indexes calculated for all the species in the database and statistical analysis of the data are presented in Table 5. More than $80 \%$ of the samples of both species were collected in sites which fell within the 2 rainfall intervals ranging from 301 to $900 \mathrm{~mm}$ (Table 4). While the largest number of samples of $M$. tuberculata was collected in sites which fell within the 0 to $500 \mathrm{~m}$ altitude interval, the majority of samples of $M$. victoriae came from sites which fell within the 501 to $1000 \mathrm{~m}$ interval (Table 4). There was, however, no significant difference $(p<0.05)$ between the frequency of occurrence of
M. victoriae in habitats falling within the 0 to 500 and the 501 to $1000 \mathrm{~m}$ intervals.

The results of the decision tree analyses for M. tuberculata and M. victoriae are depicted in Figs. 2 and 3 respectively.

\section{Discussion}

The 85 loci from which the 305 samples of M. tuberculata were recovered, display a continuous distribution all along the eastern border of South Africa from Limpopo Province down to the southern border of KwaZulu-Natal Province (Fig. 1). It is discontinuously spread through the north-western part of Limpopo and 
a focus of 6 loci occurs on the border of North West and Gauteng. The occurrence of this species in 2 isolated loci in the Northern Province far outside its endemic range of distribution seems rather unusual. However, samples of $M$. tuberculata, closely associated with Biomphalaria pfeifferi (snail intermediate host of Schistosoma mansoni) were recovered on more than one occasion from the Kuruman River and its eye (source) situated in these loci in the Kuruman district. The presence of freshwater snails in dolomitic springs in South Africa far outside their endemic range of distribution is discussed in detail in De Kock and Wolmarans
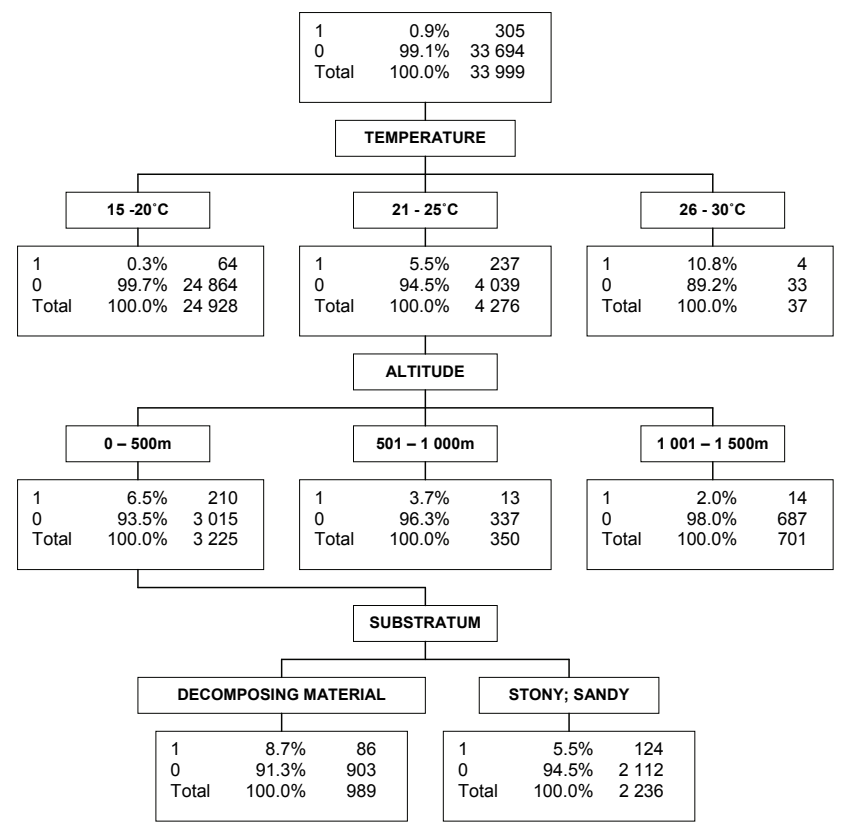

Figure 2

Decision tree of the frequency of occurrence of Melanoides tuberculata for each variable as compared to the frequency of occurrence of all the other species in the database of the National Freshwater Snail Collection. 0: percentages and frequencies of all other species, 1: percentages and frequencies of M. tuberculata. (2004a). These springs usually have a stabilising effect on both water temperature and water supply, factors which play an important role in making water-bodies suitable for colonisation by freshwater snails outside their endemic range of distribution.

Owing to the fact that the geographical distribution of both $M$. tuberculata and $M$. victoriae displays a westerly arm extending from the eastern part of South Africa, they are classified as broadly tropical by Brown (1978) compared to narrowly tropical species having no westerly arm. However, from the effect sizes calculated for the temperature indexes (Table 5) it is evident that $M$. tuberculata did not differ significantly in respect of its association with warm climatic temperatures $(d<0.5)$ from 10 of the 12 species classified as narrowly tropical by Brown (1978).

Table 3

Substratum types in the habitats of Melanoides tuberculata and $M$. victoriae as described during surveys

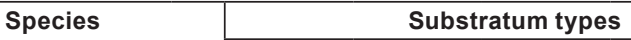

\begin{tabular}{|c|c|c|c|c|c|}
\hline & \multirow{3}{*}{\begin{tabular}{|c|} 
Muddy \\
86 \\
\end{tabular}} & \multirow{3}{*}{\begin{tabular}{|c|} 
Stony \\
28 \\
\end{tabular}} & \multirow{3}{*}{$\begin{array}{c}\text { Sandy } \\
76 \\
\end{array}$} & \multirow{3}{*}{\begin{tabular}{|c|}
$\begin{array}{c}\text { Decomposing } \\
\text { material }\end{array}$ \\
13 \\
\end{tabular}} \\
\hline & & & & & \\
\hline \multirow{5}{*}{$\begin{array}{l}\text { Melanoides } \\
\text { tuberculata } \\
\quad * 305\end{array}$} & A & & & & \\
\hline & $\mathrm{B}$ & $28.2 \%$ & $9.2 \%$ & $24.9 \%$ & $4.3 \%$ \\
\hline & $\mathrm{C}$ & 12835 & 7934 & 6523 & 632 \\
\hline & $\mathrm{D}$ & $0.7 \%$ & $0.4 \%$ & $1.2 \%$ & $2.1 \%$ \\
\hline & E & \multicolumn{4}{|c|}{$w=0.5$ (large effect) } \\
\hline \multirow{5}{*}{$\begin{array}{l}\text { Melanoides } \\
\text { victoriae } \\
\quad * 53\end{array}$} & $\mathrm{~A}$ & 8 & 16 & 16 & 1 \\
\hline & $\mathrm{B}$ & $15.1 \%$ & $30.2 \%$ & $30.2 \%$ & $1.9 \%$ \\
\hline & $\mathrm{C}$ & 12835 & 7934 & 6523 & 632 \\
\hline & $\mathrm{D}$ & $0.06 \%$ & $0.2 \%$ & $0.2 \%$ & $0.2 \%$ \\
\hline & E & \multicolumn{4}{|c|}{$w=0.5$ (large effect) } \\
\hline \multirow{3}{*}{\multicolumn{6}{|c|}{$\begin{array}{ll}\text { A } & \begin{array}{l}\text { Number of times collected in a water-body with a specific } \\
\text { substratum }\end{array} \\
B \quad \% \text { of the total number of collections on record for each species } \\
C & \begin{array}{l}\text { Number of times any mollusc was collected in a water-body with } \\
\text { a specific substratum }\end{array}\end{array}$}} \\
\hline & & & & & \\
\hline & & & & & \\
\hline \multicolumn{6}{|c|}{$\begin{array}{l}D \% \text { occurrence of each species in the total number of collections } \\
\text { in a water-body with a specific substratum }\end{array}$} \\
\hline $\begin{array}{ll}E & \text { effect size } \\
* & \text { Number }\end{array}$ & & $\begin{array}{l}\text { s calcula } \\
\text { ctions on }\end{array}$ & $\begin{array}{l}\text { d for subs } \\
\text { ecord for }\end{array}$ & $\begin{array}{l}\text { atum type } \\
\text { ach specie }\end{array}$ & \\
\hline
\end{tabular}

\begin{tabular}{|c|c|c|c|c|c|c|c|c|c|c|c|c|}
\hline & & $\begin{array}{l}\text { ncy dist } \\
\text { intervals }\end{array}$ & $\begin{array}{l}\text { ution } \\
\text { f mean }\end{array}$ & $\begin{array}{l}\text { the coll } \\
\text { inual ai }\end{array}$ & $\begin{array}{l}\text { tion sit } \\
\text { empera }\end{array}$ & $\begin{array}{l}\text { Table } 4 \\
\text { of Melan } \\
\text { are and ra }\end{array}$ & $\begin{array}{l}\text { oides tub } \\
\text { infall and }\end{array}$ & $\begin{array}{l}\text { rculata } \\
\text { nean al }\end{array}$ & $\begin{array}{l}\text { d } M . \text { vic } \\
\text { Ide in S }\end{array}$ & $\begin{array}{l}\text { riae in } \\
\text { th Afri }\end{array}$ & cted & \\
\hline Species & & Tempe & ture inte & als ${ }^{\circ} \mathrm{C}$ & & Rainfo & Ill intervals & $\mathrm{mm})$ & & Alti & e interv & (m) \\
\hline & & $16-20$ & $21-25$ & $26-30$ & $0-300$ & $301-600$ & $601-900$ & $\begin{array}{l}901- \\
1200 \\
\end{array}$ & $\begin{array}{c}1201- \\
1500 \\
\end{array}$ & $0-500$ & $\begin{array}{l}501- \\
1000 \\
\end{array}$ & $\begin{array}{c}1001- \\
1500 \\
\end{array}$ \\
\hline Melanoides & A & 64 & 237 & 4 & 9 & 131 & 143 & 21 & 1 & 220 & 41 & 44 \\
\hline tuberculata & $\mathrm{B}$ & $21.0 \%$ & $77.7 \%$ & $1.3 \%$ & $3.0 \%$ & $43.0 \%$ & $46.9 \%$ & $6.9 \%$ & $0.3 \%$ & $72.1 \%$ & $13.4 \%$ & $14.4 \%$ \\
\hline & $\mathrm{C}$ & 24928 & 4276 & 37 & 975 & 11994 & 19799 & 1203 & 28 & 6747 & 4491 & 14918 \\
\hline & $\mathrm{D}$ & $0.3 \%$ & $5.5 \%$ & $10.8 \%$ & $0.9 \%$ & $1.1 \%$ & $0.7 \%$ & $1.7 \%$ & $3.6 \%$ & $3.3 \%$ & $0.9 \%$ & $0.3 \%$ \\
\hline & $\mathrm{E}$ & $w=1$ & (large & ect) & & $=0.3(\mathrm{sm}$ & all to mod & rate effe & & $w=$ & 3 (large & fect) \\
\hline Melanoides & A & 29 & 23 & 1 & 2 & 23 & 21 & 7 & 0 & 17 & 28 & 8 \\
\hline victoriae & B & 54.7 & 43.4 & 1.9 & 3.8 & 43.4 & 39.6 & 13.2 & 0.0 & 32.1 & 52.8 & 15.1 \\
\hline & $\mathrm{C}$ & 24928 & 4276 & 37 & 975 & 11994 & 19799 & 1203 & 28 & 6747 & 4491 & 14918 \\
\hline & $\mathrm{D}$ & 0.1 & 0.5 & 2.7 & 0.2 & 0.2 & 0.1 & 0.6 & 0.0 & 0.3 & 0.6 & 0.1 \\
\hline & $\mathrm{E}$ & $w=($ & (large & fect) & & $w=$ & 6 (large e & fect) & & $w=$ & 2 (large & fect) \\
\hline $\begin{array}{l}\text { A Number of } \\
B \% \text { of the tot } \\
C \text { Number of } \\
D \% \text { occurrer } \\
E \text { Effect size } \\
* \text { Number of }\end{array}$ & il & $\begin{array}{l}\text { ollected in } \\
\text { ber of coll } \\
\text { ny mollus } \\
\text { ach specie } \\
\text { alculated } \\
\text { ons on rec }\end{array}$ & $\begin{array}{l}\text { locality } \\
\text { tions on } \\
\text { as colle } \\
\text { in the tot } \\
\text { reach fa } \\
\text { d for eac }\end{array}$ & $\begin{array}{l}\text { ling with } \\
\text { cord for } \\
\text { d in a lo } \\
\text { number } \\
\text { or } \\
\text { species }\end{array}$ & $\begin{array}{l}\text { a specif } \\
\text { h speci } \\
\text { ity falli } \\
\text { ollectic }\end{array}$ & $\begin{array}{l}\text { terval } \\
\text { ithin as } \\
\text { vithin a }\end{array}$ & $\begin{array}{l}\text { ecific inter } \\
\text { ecific inte }\end{array}$ & & & & & \\
\hline
\end{tabular}




\begin{tabular}{|c|c|c|c|c|c|c|c|c|c|c|}
\hline \multicolumn{11}{|c|}{$\begin{array}{rr}\text { Table } 5 \\
\text { Frequency distribution in temperature intervals and te }\end{array}$} \\
\hline Mollusc species & \begin{tabular}{|c|} 
No. of \\
samples
\end{tabular} & $6-10^{\circ} \mathrm{C}$ & $\begin{array}{c}11- \\
15^{\circ} \mathrm{C}\end{array}$ & $16-20^{\circ} \mathrm{C}$ & $21-25^{\circ} \mathrm{C}$ & $\begin{array}{c}26- \\
30^{\circ} \mathrm{C}\end{array}$ & ${ }^{1}$ Index & ${ }^{2} \mathrm{SD}$ & ${ }^{3} \mathrm{CV}$ & $\begin{array}{c}\text { Effect } \\
\text { size } \\
d\end{array}$ \\
\hline Pisidium viridarium & 639 & 201 & 271 & 164 & 3 & & 1.947 & 0.764 & 39.22 & -4.317 \\
\hline Lymnaea truncatula & 723 & 95 & 281 & 343 & 4 & & 2.354 & 0.709 & 30.14 & -3.370 \\
\hline Pisidium casertanum & 5 & & 2 & 3 & & & 2.600 & 0.548 & 21.07 & -2.798 \\
\hline Pisidium langleyanum & 632 & 18 & 173 & 435 & 6 & & 2.676 & 0.544 & 20.33 & -2.620 \\
\hline Pisidium costulosum & 428 & 1 & 139 & 284 & 4 & & 2.680 & 0.492 & 18.34 & -2.612 \\
\hline Bulinus tropicus & 8448 & 32 & 2326 & 5860 & 230 & & 2.744 & 0.502 & 18.31 & -2.462 \\
\hline Gyraulus connollyi & 969 & & 185 & 777 & 7 & & 2.816 & 0.406 & 14.40 & -2.295 \\
\hline Ceratophallus natalensis & 1797 & & 299 & 1430 & 68 & & 2.871 & 0.433 & 15.09 & -2.166 \\
\hline Burnupia (all species) & 2778 & 7 & 287 & 2384 & 100 & & 2.928 & 0.380 & 12.97 & -2.036 \\
\hline Ferrissia (all species) & 540 & & 72 & 420 & 47 & 1 & 2.957 & 0.476 & 16.09 & -1.966 \\
\hline Bulinus reticulatus & 296 & & 6 & 287 & 3 & & 2.990 & 0.174 & 5.83 & -1.891 \\
\hline Assiminea umlaasiana & 2 & & & 2 & & & 3.000 & 0.000 & 0.00 & -1.867 \\
\hline Tomichia cawstoni & 4 & & & 4 & & & 3.000 & 0.000 & 0.00 & -1.867 \\
\hline Tomichia differens & 10 & & & 10 & & & 3.000 & 0.000 & 0.00 & -1.867 \\
\hline Tomichia lirata & 2 & & & 2 & & & 3.000 & 0.000 & 0.00 & -1.867 \\
\hline Tomichia ventricosa & 89 & & & 89 & & & 3.000 & 0.000 & 0.00 & -1.867 \\
\hline Tomichia tristis & 81 & & & 79 & 2 & & 3.025 & 0.156 & 5.16 & -1.810 \\
\hline Unio caffer & 76 & & 6 & 63 & 6 & 1 & 3.026 & 0.461 & 15.24 & -1.806 \\
\hline Physa acuta & 755 & & & 719 & 36 & & 3.048 & 0.213 & 7.00 & -1.757 \\
\hline Bulinus depressus & 552 & & & 519 & 33 & & 3.060 & 0.237 & 7.76 & -1.728 \\
\hline Arcuatula capensis & 15 & & & 14 & 1 & & 3.067 & 0.258 & 8.42 & -1.712 \\
\hline Lymnaea columella & 2302 & & 81 & 1977 & 243 & 1 & 3.071 & 0.371 & 12.07 & -1.702 \\
\hline Lymnaea natalensis & 4721 & & 205 & 3802 & 713 & 1 & 3.108 & 0.429 & 13.79 & -1.616 \\
\hline Assiminea bifasciata & 17 & & & 15 & 2 & & 3.118 & 0.332 & 10.65 & -1.594 \\
\hline Gyraulus costulatus & 736 & & 20 & 580 & 135 & 1 & 3.159 & 0.437 & 13.84 & -1.498 \\
\hline Bulinus forskalii & 1209 & & 17 & 985 & 204 & 3 & 3.160 & 0.409 & 12.95 & -1.496 \\
\hline Pisidium ovampicum & 7 & & & 5 & 2 & & 3.167 & 0.408 & 12.89 & -1.480 \\
\hline Sphaerium capense & 25 & & 1 & 17 & 7 & & 3.240 & 0.523 & 16.14 & -1.309 \\
\hline Bulinus africanus group & 2930 & & 9 & 2155 & 760 & 6 & 3.260 & 0.450 & 13.82 & -1.262 \\
\hline Corbicula fluminalis & 390 & & 1 & 291 & 94 & 4 & 3.267 & 0.437 & 13.38 & -1.246 \\
\hline Tomichia natalensis & 23 & & & 16 & 7 & & 3.304 & 0.470 & 14.24 & -1.160 \\
\hline Thiara amarula & 10 & & & 6 & 4 & & 3.400 & 0.516 & 15.19 & -0.937 \\
\hline Assiminea ovata & 5 & & & 3 & 1 & & 3.400 & 0.548 & 16.11 & -0.937 \\
\hline Melanoides victoriae & 53 & & & 29 & 23 & 1 & 3.429 & 0.540 & 15.75 & -0.871 \\
\hline Biomphalaria pfeifferi & 1639 & & 5 & 880 & 751 & 3 & 3.459 & 0.508 & 14.69 & -0.800 \\
\hline Septaria tesselaria & 2 & & & 1 & 1 & & 3.500 & 0.707 & 20.20 & -0.705 \\
\hline Coelatura framesi & 6 & & & 3 & 3 & & 3.500 & 0.548 & 15.65 & -0.705 \\
\hline Neritina natalensis & 16 & & & 8 & 8 & & 3.500 & 0.516 & 14.75 & -0.705 \\
\hline Bulinus natalensis & 245 & & 2 & 97 & 146 & & 3.588 & 0.510 & 14.20 & -0.501 \\
\hline${ }^{4}$ Segmentorbis planodiscus & 27 & & & 9 & 18 & & 3.667 & 0.480 & 13.10 & -0.317 \\
\hline${ }^{4}$ Segmentorbis angustus & 32 & & & 7 & 25 & & 3.781 & 0.420 & 11.11 & -0.051 \\
\hline Melanoides tuberculata & 305 & & & 64 & 237 & 4 & 3.803 & 0.430 & 11.30 & 0.000 \\
\hline${ }^{4}$ Pisidium pirothi & 39 & & & 4 & 35 & & 3.826 & 0.388 & 10.13 & 0.054 \\
\hline${ }^{4}$ Chambardia wahlbergi & 41 & & & 10 & 30 & 1 & 3.932 & 0.398 & 10.11 & 0.300 \\
\hline Aplexa marmorata & 9 & & & & 9 & & 4.000 & 0.000 & 0.00 & 0.458 \\
\hline${ }^{4}$ Bellamya capillata & 31 & & & & 31 & & 4.000 & 0.000 & 0.00 & 0.458 \\
\hline${ }^{4}$ Eupera ferruginea & 169 & & & 6 & 157 & 6 & 4.000 & 0.267 & 6.68 & 0.458 \\
\hline${ }^{4}$ Lentorbis carringtoni & 8 & & & & 8 & & 4.000 & 0.000 & 0.00 & 0.458 \\
\hline${ }^{4}$ Lentorbis junodi & 12 & & & & 12 & & 4.000 & 0.000 & 0.00 & 0.458 \\
\hline${ }^{4}$ Segmentorbis kanisaensis & 9 & & & & 9 & & 4.000 & 0.000 & 0.00 & 0.458 \\
\hline${ }^{4}$ Chambardia petersi & 39 & & & 1 & 36 & 2 & 4.000 & 0.272 & 6.80 & 0.458 \\
\hline${ }^{4}$ Cleopatra ferruginea & 73 & & & & 71 & 2 & 4.027 & 0.164 & 4.08 & 0.522 \\
\hline${ }^{4}$ Lanistes ovum & 41 & & & & 38 & 3 & 4.073 & 0.264 & 6.47 & 0.628 \\
\hline
\end{tabular}




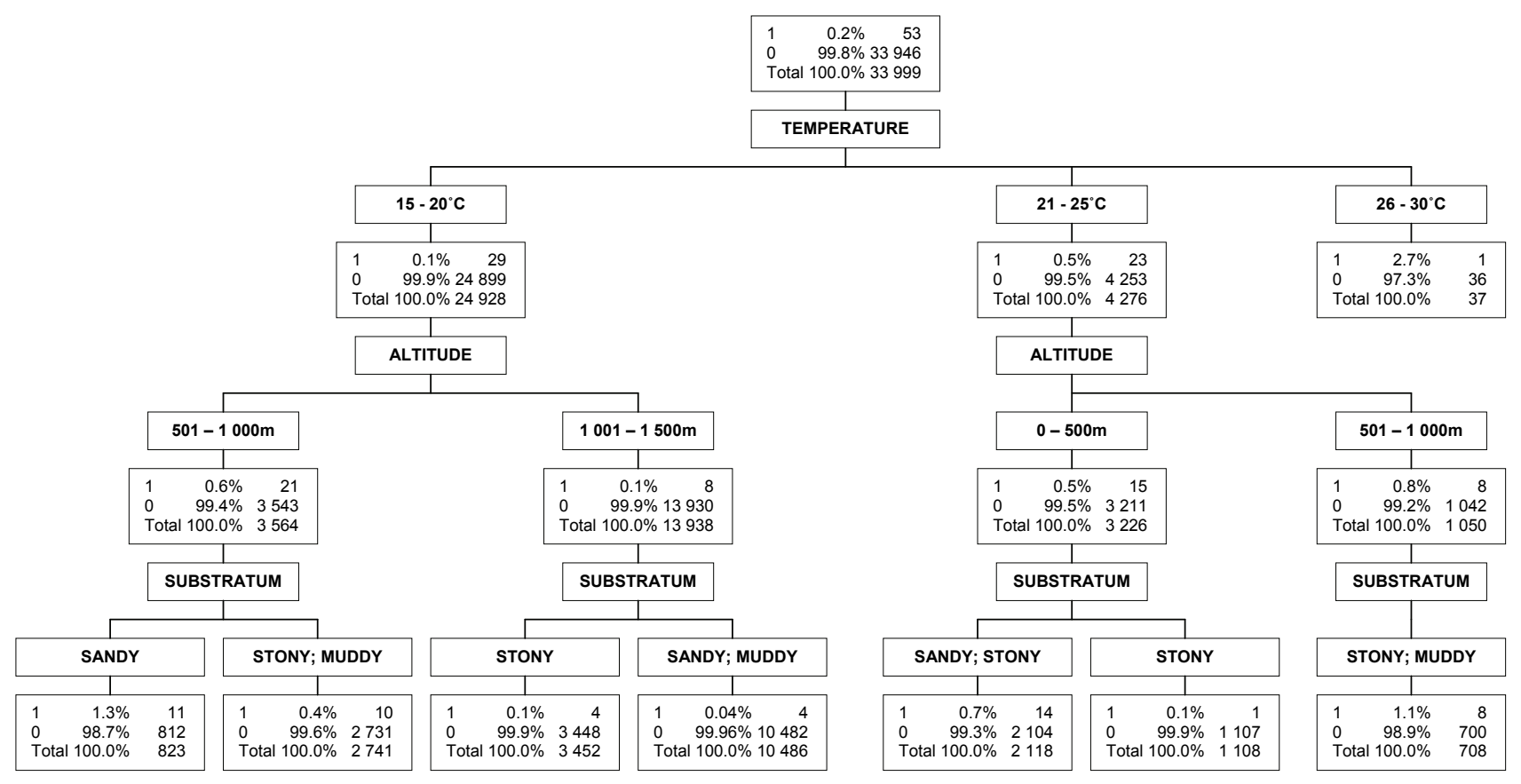

Figure 3

Decision tree of the frequency of occurrence of Melanoides victoriae for each variable as compared to the frequency of occurrence of all the other species in the database of the National Freshwater Snail Collection. 0 : percentages and frequencies of all other species, 1: percentages and frequencies of $\mathrm{M}$. victoriae.

According to Brown (1994) the southern limit of the distribution of M. tuberculata in the eastern part of South Africa lies near Port Elizabeth. However, despite the fact that we have many records of other freshwater mollusc species in the database of which the southern limits of distribution extend even further than Port Elizabeth (De Kock et al., 1989; De Kock et al., 2001; De Kock et al., 2002a; De Kock and Wolmarans, 2004b; De Kock and Wolmarans, 2005c; De Kock and Wolmarans, 2007), we have none for this species extending further southwards than the southern border of KwaZulu-Natal. Twelve of the 21 loci on record for M. victoriae are shared with M. tuberculata; however, it is not as widespread as the latter species (Fig. 1). Appleton (2002) mentions that M. victoriae is not known from KwaZulu-Natal; however, we have 4 samples on record from this Province collected during 1965 and 1966 which is now reported for the first time.

The fact that M. tuberculata was recovered from 12 of the 14 water-body types represented in the database (Table 1) confirms the report by Brown (1994) that it can utilise various permanent water-bodies including rivers, shallow seepages and man-made habitats. In contrast to this, $M$. victoriae was reported from only 6 different water-body types and obviously seemed to prefer perennial rivers (Tables 1 and 2) which is the only water-body type mentioned for this particular species for the Mpumalanga Lowveld by Brown (1994). The 5 samples on record for M. tuberculata from habitats with brackish water also support the report by Brown (1994) that this species is tolerant of moderate brackishness in coastal localities. According to this author M. tuberculata is not found in temporary waters; however, we have 14 samples on record in the database reported from seasonal habitats for this species and also 1 sample of $M$. victoriae from a temporary habitat (Table 2). Although more samples of $M$. tuberculata were reported from water-bodies with standing water than with slow running water (Table 2) no significant differences could be indicated between these alternatives. In contrast more samples of $M$. victoriae were recovered from water-bodies with slow running water than with standing water (Table 2) and in this instance a significant difference ( $\mathrm{p}<$ 0.05 ) could be indicated. From the effect values calculated for water velocity it is evident, however, that this factor played a much more important role in determining the presence, or not, of $M$. victoriae in a specific water-body. The majority of samples of both species were reported from water-bodies with water described as clear (Table 2) but no significant differences were found between their occurrence in habitats with clear or muddy water and the effect sizes calculated for this parameter also indicated that turbidity did not play an important role in determining the suitability of a given water-body.

Nearly $78 \%$ of the samples of $M$. tuberculata were recovered from loci which fell within the temperature interval ranging from $21^{\circ} \mathrm{C}$ to $25^{\circ} \mathrm{C}$ while the interval ranging from $16^{\circ} \mathrm{C}$ to $20^{\circ} \mathrm{C}$ yielded the largest number of samples of $M$. victoriae (Table 4). These results are supported by the temperature indexes calculated for these 2 species which indicated that the former species not only seemed more closely associated with warmer climatic temperatures but the effect sizes calculated for these indexes also showed that it differed significantly $(d>0.5)$ from $M$. victoriae in this respect (Table 5). Although only 4 samples of M. tuberculata were recovered from sites which fell within the temperature interval ranging between $26^{\circ} \mathrm{C}$ and $30^{\circ} \mathrm{C}$ it represented $10.8 \%$ of the total number of collections of all molluscs in the database from sites falling within this specific temperature interval (Table 4 and Fig. 2). This also points to a relatively close association with higher climatic temperatures.

From the effect-size values calculated for the various parameters investigated (Tables 1 to 4 ) it can be deduced that temperature, altitude, substratum and water-bodies, played an important role in establishing the geographical distribution of both species as reflected by the data in the database of the NFSC. This deduction is supported by the results of the decision tree analyses (Figs. 2 and 3) which selected temperature, altitude and substratum as the most important factors which 
had significantly influenced the geographical distribution of both species. From the decision tree analyses it can further be seen that a substratum consisting of mainly decomposing material played a significant role in the habitats from which samples of $M$. tuberculata were recovered (Fig. 2).

With regard to their habitat preferences it can be concluded that both species seemed to prefer perennial rivers in areas which fell within the temperature intervals ranging from $16^{\circ} \mathrm{C}$ to $25^{\circ} \mathrm{C}$ and altitude intervals ranging from 500 to $1500 \mathrm{~m}$ a.m.s.l. However, the results in Table 1 suggest that $M$. victoriae is considerably more stenoecious than M. tuberculata. Current velocity in a water-body and mean yearly rainfall also seemed to play a significant role in the presence or not of the former species in a specific area (Tables 2 and 4).

As mentioned earlier M. tuberculata has become invasive after introduction into new areas such as Martinique Island (Pointier, 2001) and Brazil (Rocha-Miranda and Martins-Silva, 2006) but fortunately in both these cases it proved to be an efficient and sustainable control agent of intermediate host snails responsible for the transmission of schistosomiasis to humans. Apparently this is not the case in South Africa because we have a number of samples on record in the database of the NFSC, amongst others from the Kruger National Park, where persistent populations of both the local schistosome intermediate host snail species and populations of M. tubercuata have co-existed in the same water-body through several decades.

Although numerous cases of $M$. tuberculata becoming a nuisance species in tropical fish aquaria have been reported in literature, we are not aware of any case recorded in literature of this species causing problems in natural water-bodies in South Africa. According to Appleton (2002), however, it has become plentiful in rice paddies in KwaZulu-Natal and we were recently approached for advice on a case where M. tuberculata had proliferated to such an extent after invading the heat exchanger of an electric power-plant that it caused complete clogging of the filters, resulting in malfunctioning of the entire system.

Countrywide surveys for freshwater molluscs was terminated during the early 1980s and on account of the fact that many of the positive sites were not revisited, comments on the conservation status of our mollusc fauna should be made with circumspection. However, Melanoides localities reported from the Kruger National Park by Oberholzer and Van Eeden (1967) have since been revisited in surveys conducted by ourselves in 1995 (De Kock and Wolmarans, 1998), 2001 (De Kock et al., 2002b) and 2006 (Wolmarans and De Kock, 2006) and a marked decline in positive localities, as well as in population size, were evident for both species. Whereas Oberholzer and Van Eeden (1967) reported 34 and 20 positive sites for M. tuberculata and M. victoriae respectively, only 4 sites and 1 site for these species, respectively, were found positive during our extensive survey in 2006. The only prosobranch snail that was encountered in large numbers in some of the sites during our 2006 survey was the exotic invader species Tarebia granifera which was reported for the first time in Africa by Appleton and Nadasan (2002). According to Pointier and McCullough (1989) this species has demonstrated its capacity to invade and rapidly colonize a wide range of water-body types on numerous islands and countries in the Neotropical area and succeeded in reducing and even eliminating populations of other mollusc species. Whether the invasion of water-bodies in the Kruger National Park by this exotic species could have a bearing on the observed decline in positive sites of both Melanoides spp. needs further investigation.

From the literature it is clear that M. tuberculata can serve as intermediate host for several trematode species which can be harmful to a number of vertebrate species, including man. These include amongst others, Clonorchis sinensis, the Oriental liverfluke (Lun et al., 2005) and Philopthalmus gralli, a trematode infecting the eyes of bird species but also reported infecting humans (Díaz et al. 2002). Melanoides tuberculata was also proved to be a compatible intermediate hosts for Gastrodiscus aegyptiacus, the fluke responsible for gastrodiscosis in equine populations in Zimbabwe (Mukaratirwa et al., 2004) and Calicophoron microbothrium another trematode fluke of veterinary importance in that country (Chingwena et al., 2002). Furthermore, specimens of $M$. tuberculata infected with larval stages of economically important intestinal flukes of the family Heterophyidae were reported from the Rio de Janeiro metropolitan area, Brazil (Bogéa et al., 2005). Melanoides tuberculata was also reported from Australia as the intermediate host of the trematode, Transotrema licinum an ectoparasite of several fish species (Manter, 1970) and evidence was also put forward by Frandsen and Christensen (1984) that M. tuberculata could be an important intermediate host for several fluke species. Shedding of non-schistosome cercariae was also reported for M. tuberculata from the Msambweni area, Coast Province, Kenya (Kariuki et al., 2004).

Due to the fact that M. tuberculata is relatively easy to cultivate and maintain in the laboratory, it has been utilised locally as bio-indicator to assess biological effects of diffuse sources of pollutants in a wetland system (Wepener et al., 2005) and in comparative studies in the laboratory on the uptake and effects of heavy metals on cellular energy and allocation (Moolman et al., 2007). Studies on the life cycle and growth of M. tuberculata were also conducted in a natural habitat in Mpumalanga (Appleton, 1974). To our knowledge, however, the capacity of representatives of the 2 local Melanoides species to serve as intermediate hosts for parasitic flukes has not yet been investigated. However, after eggs resembling those of Paragonimus kellicotti, a lung fluke infecting cats and dogs, were reported from humans and cats in KwaZulu-Natal (Proctor and Gregory, 1974), circumstantial evidence implicated M. tuberculata as the intermediate host because it was the only prosobranch snail that could be found in the area at that stage.

In view of the important role played by M. tuberculata in the epidemiology of a number of trematode species of medical and veterinary importance elsewhere in the world, it is recommended that the ability to act as intermediate hosts for economically important trematode flukes of both the Melanoides species occurring in South Africa should be investigated. At the same time efforts should be made to update the geographical distribution of both species and to compare the results with existing records in the database of the NFSC to evaluate their conservation status. The ability of $M$. tuberculata to aestivate was listed as a poor by Brown (1994) and the fact that perennial rivers seemed to be the water-body of preference for both species could be a disadvantage for their long-term survival. Increased evaporation of surface water due to global warming could have a detrimental effect on the permanency of such water-bodies and suitable habitats could become less available which in turn could impact negatively on their geographical distribution and conservation status in this country. As mentioned earlier $M$. victoriae seemed to be considerably more stenoecious than $M$. tuberculata and therefore more prone to be affected by changes in environmental conditions. Taking into account the relatively limited geographical distribution reported for $M$. victoriae and the results of our recent surveys in the Kruger National Park, the conservation status of this species could justifiably be considered as vulnerable. 


\section{Acknowledgements}

The authors wish to thank the following persons for their assistance in processing the data: Professors HS Steyn, head of the Statistical Consulting Service and DA de Waal of the Centre for Business Mathematics and Informatics of the North-West University, Potchefstroom Campus. We are also indebted to the North-West University for financial support and infrastructure.

\section{References}

APPLETON CC (1974) The population fluctuation of five fresh-water snail species in the Eastern Transvaal Lowveld, and their relationship to known bilharzia transmission patterns. S. Afr. J. Sci. 70 145-150.

APPLETON CC (2002) Mollusca. In: De Moor IJ and Day JA (eds.) Guides to the Freshwater Invertebrates of Southern Africa (Volume 6) Chapter 3: Arachnida \& Mollusca, Araneae, Water Mites \& Mollusca. WRC Report No. 182/02. Water Research Commission, Pretoria, South Africa. 42-125.

APPLETON CC and NADASAN DS (2002) First report of Tarebia granifera (Lamarck, 1816) (Gastropoda: Thiaridae) from Africa. J. Moll. Stud. 68 399-402.

BOGÉA T, CORDEIRO FM and DE GOUVEIA JS (2005) Melanoides tuberculatus (Gastropoda: Thiaridae) as intermediate host of Heterophyidae (Trematoda: Digenea) in Rio de Janeiro metropolitan area, Brazil. Rev. Inst. Med. Trop. São Paulo. 47 87-90.

BREIMAN L, FRIEDMAN JH, OLSHEN RA and STONE CJ (1984) Classification and Regression Trees. Chapman and Hall.

BROWN DS (1978) Freshwater molluscs: In: Werger MJA (ed.) Biogeography and Ecology of Southern Africa. Junk, The Haque, The Netherlands. 1153-1180.

BROWN DS (1994) Freshwater Snails of Africa and their Medical Importance (revised $2^{\text {nd }}$ edn.). Taylor \& Francis, London.

CHINGWENA G, MUKARATIRWA S, KRISTENSEN TK and CHIMBARI M (2002) Susceptibility of freshwater snails to the amphistome Calicophoron microbothrium and the influence of the species on susceptibility of Bulinus tropicus to Schistosoma haematobium and Schistosoma mattheei infections. J. Parasitol. 88 880-883.

COHEN J (1977) Power Analysis for the Behaviour Sciences (revised edn.). Academic Press, Orlando, USA.

DE KOCK KN, JOUBERT PH and PRETORIUS SJ (1989) Geographical distribution and habitat preferences of the invader freshwater snail species Lymnaea columella (Mollusca: Gastropoda) in South Africa. Onderstepoort J. Vet. Res. 56 271-275.

DE KOCK KN and WOLMARANS CT (1998) A re-evaluation of the occurrence of freshwater molluscs in the Kruger National Park. Koedoe 41 1-8.

DE KOCK KN and WOLMARANS CT (2004a) Distribution and habitats of Biomphalaria pfeifferi, snail intermediate host of Schistosoma mansoni, in South Africa. Water SA 30 29-36.

DE KOCK KN and WOLMARANS CT (2004b) Verspreiding en habitats van Gyraulus connollyi, slaktussengasheer van ingewandsbotte van die familie Echinostomatidae, in Suid-Afrika. S. Afr. Tydskr. Natuurwet. Teg. 23 79-86.

DE KOCK KN and WOLMARANS CT (2005a) Distribution and habitats of the Bulinus africanus species group, snail intermediate hosts of Schistosoma haematobium and S. mattheei in South Africa. Water SA 31 117-126.

DE KOCK KN and WOLMARANS CT (2005b) Distribution and habitats of Bulinus depressus and possible role as intermediate host of economically important helminth parasites in South Africa. Water SA 31 491-496.

DE KOCK KN and WOLMARANS CT (2005c) Distribution, habitats and role as intermediate host of the freshwater snail, Bulinus forskalii, in South Africa. Onderstepoort J. Vet. Res. 72 165-174.

DE KOCK KN and WOLMARANS CT (2007) Verspreiding en habitats van Ceratophallus natalensis (Mollusca: Planorbidae) in
Suid-Afrika. S. Afr. Tydskr. Natuurwet. Teg. 26 109-119.

DE KOCK KN, WOLMARANS CT, BORNMAN M and MAREE DC (2002a) Verspreiding en habitats van Bulinus tropicus, tussengasheerslak van die peervormige bot, Calicophoron microbothrium, in Suid-Afrika. S. Afr. Tydskr. Natuurwet. Teg. 21 114-120.

DE KOCK KN, WOLMARANS CT and DU PREEZ LH (2002b) Freshwater mollusc diversity in the Kruger National Park: a comparison between a period of prolonged drought and a period of exceptionally high rainfall. Koedoe 45 1-11.

DE KOCK KN, WOLMARANS CT, STRAUSS HD and KILLIAN M (2001) Verspreiding en habitats van Lymnaea natalensis, tussengasheerslak van die lewerbot Fasciola gigantica, in Suid-Afrika. S. Afr. Tydskr. Natuurwet. Teg. 20 49-53.

DÍAZ MT, HERNÁNDEZ LE and BASHIRULLAH AK (2002) Experimental life cycle of Philophtalmus gralli (Trematoda: Philopthalmidae) in Venezuela. Rev. Biol. Trop. 50 629-641.

FRANDSEN F and CHRISTENSEN NØ (1984) An introductory guide to the identification of cercariae from African freshwater snails with special reference to cercariae of trematode species of medical and veterinary importance. Acta Trop. 41 181-202.

KARIUKI HC, CLENNON JA, BRADY MS, KITRON U, STURROCK RF, OUMA JH, NDZOVU STM, MUNGAI P, HOFFMAN O, HAMBURGER J, PELLEGRINI C, MUCHIRI EM and KING $\mathrm{CH}$ (2004) Distribution patterns and cercarial shedding of Bulinus nasutus and other snails in the Msambweni area, Coast Province, Kenya. Am. J. Trop. Med. Hyg. 70 449-456.

LUN Z-R, GASSER RB, LAI D-H, LI A-X, ZHU X-Q, YU X-B and FANG Y-Y (2005) Clonorchiasis: a key foodborne zoonosis in China. Lancet Infec. Dis. 5 31-41.

MANTER HW (1970) A new species of Transversotrema (Trematoda: Digenea) from marine fishes of Australia. J. Parasitol. 56 486-489.

MOOLMAN L, VAN VUREN JHJ and WEPENER V (2007) Comparative studies on the uptake and effects of cadmium and zinc on the cellular energy allocation of two freshwater gastropods. Ecotoxicol. Environ. Saf. 68 443-450.

MUKARATIRWA S, MUNJERE IF, TAKAWIRA M and CHINGWENA G (2004)Susceptibility of seven freshwater gastropod species in Zimbabwe to infection with Gastrodiscus aegyptiacus (Cobbold, 1876) Looss, 1896. S. Afr. Vet. Ass. 75 186-188.

OBERHOLZER G and VAN EEDEN JA (1967) The freshwater molluscs of the Kruger National Park. Koedoe 10 1-42.

PILSBRY HA and BEQUAERT J (1927) The aquatic molluscs of the Belgian Congo, with a geographical and ecological account of Congo malacology. Bull. Amer. Mus. Nat. Hist. 53 69-602.

POINTIER J-P (2001) Invading freshwater snails and biological control in Martinique Island, French West Indies. Mem. Inst. Oswaldo Cruz 96 67-74.

POINTIER J-P and McCULLOUGH F (1989) Biological control of the snail hosts of Schistosoma mansoni in the Caribbean area using Thiara spp. Acta Tropica 46 147-155.

POTTS WJE (1999) Decision Tree Modeling Course Notes. SAS Institute Inc., Cary, USA.

PROCTOR EM and GREGORY MA (1974) An ultrastructural study of ova of Paragonimus species from human and cat faeces. S. Afr. Med. J. 48 1947-1948.

ROCHA-MIRANDA F and MARTINS-SILVA MJ (2006) First record of the invasive snail Melanoides tuberculatus (Gastropoda: Prosobranchia: Thiaridae) in the Paranã River basin, GO, Brazil. Braz. J. Biol. 66 1109-1115.

VAN DAMME D (1984) The Freshwater Mollusca of Northern Africa, Distribution, Biogeography and Palaeoecology. W Junk, Dordrecht, the Netherlands.

WEPENER V, VAN VUREN JHJ, CHATIZA FP, MBIZI Z, SLABBERT L and MASOLA B (2005) Active biomonitoring in freshwater environments: early warning signals from biomarkers in assessing biological effects of diffuse sources of pollutants. Phys. Chem. Earth 30 751-761.

WOLMARANS CT and DE KOCK KN (2006) The current status of freshwater molluscs in the Kruger National Park. Koedoe 49 39-44. 